\title{
PRÍKLADY APLIKÁCIE INDUKTÍVNEHO PRÍSTUPU VO VYUČOVANÍ TÉMATICKÉHO CELKU ZOBRAZOVANIE ZEME NA ZŠ
}

\author{
Martina Škodová
}

\begin{abstract}
The inductive way of teaching and learning has a great potential to be used in geography teaching. This article presents the theoretical framework of the possibility of inductive access in geographic education. It represents a specific design of activities in which students acquire knowledge and skills in mapping (ISCED 2) in an inductive way. Activities were designed as the part of the ExpEdition - Experience, Explore, Know project (non-profit organization Indicia). The article also presents the results of the activity verification and the results from the direct observation of teaching at 14 elementary schools in Slovakia.
\end{abstract}

Keywords: school geography, inductive approach, education, working with a map, ISCED 2

\section{Úvod}

Indukcia a dedukcia sú odjakživa spolu v dialektickej jednote, podobne ako analýza a syntéza, a potreba prítomnosti obidvoch prístupov $\mathrm{v}$ pojmotvornom procese je neodškriepitel'ná (Schubertová, 2018). I ked' v slovenských školách vo vyučovaní stále prevláda deduktívny spôsob vyučovania (Held a kol., 2011), vzniká mnoho projektov rozvíjajúcich induktívny spôsob vyučovania a učenia sa. Tento trend podporujú aj rozhodnutia európskej komisie na základe výsledkov výskumu v oblasti kvality a procesu prírodovedného vzdelávania (Minárechová, 2014). Väčšina projektov a výskumov je však zameraná na vzdelávaciu oblast' Človek a príroda (chémia, biológia a fyzika). Smerovanie k induktívnemu prístupu však môžeme nájst' aj vo vzdelávacej oblasti Človek a spoločnost'. Jej metodika $\mathrm{v}$ rámci IŠVP odporúča aplikáciu metód, z ktorých potom vyplývajú činnosti žiakov, ako je vlastné aktívne objavovanie, hl'adanie, prieskum, pátranie, tvorenie a pod. Práve v takýchto činnostiach sa efektívnejšie rozvíja komplex kompetencií žiakov - teda spôsobilostí, schopností využívat' kvalitu získaných znalostí v rôznych poznávacích i praktických situáciách (ŠPÚ, 2014). Ako však tento prístup preniest' do školskej praxe? Ciel'om príspevku je na konkrétnych príkladoch prezentovat' možnosti induktívneho prístupu v geografickom vzdelávaní. Stručne predstavujeme súbor takto koncipovaných aktivít pre tému Zobrazovanie Zeme vo vyučovaní geografie v 5. ročníku (na úrovni vzdelávania ISCED 2). 


\section{Teoreticko-metodické východiská}

Deduktívny a induktívny prístup predstavuje dva diametrálne odlišné prístupy k realizácii výučby. Deduktívny prístup vo vyučovaní geografie je charakteristický priamym prenosom (transmisiou) poznatkov od učitel'a k žiakovi. Vyučovanie zvyčajne začína vysvetlením témy, jej všeobecných princípov, zavedením pojmov, často sa predvedie model a ukáže jeho aplikácia na príklade. Následne žiaci riešia úlohy s podobnými príkladmi aplikácie a nakoniec sa testom overuje schopnost' žiakov urobit' to isté (Pasch a kol., 1998). Rolou žiakov v takto koncipovanej výuke je byt' viac-menej pasívnym prijímatel'om poznatkov, ktoré im učitel' predkladá (Tóthová a kol., 2017). Tento prístup však môže byt' aj efektívny, podmienkou však je, aby väčšina žiakov bola dostatočne vnútorne motivovaná a schopná mysliet' abstraktne. Menej úspešný (napr. podl'a výskumov Pasch a kol., 1998) je pri rozvoji tvorivého myslenia či napĺñaní ciel'ov afektívneho charakteru a vytváraní pozitívneho postoja k učeniu.

Druhým, do značnej miery protikladným prístupom k výučbe je induktívny prístup, ktorý sa v literatúre označuje aj ako bádatel'ský či výskumný (v prostredí vyučovania prírodných vied), alebo problémový (v prostredí vyučovania matematiky). Patrí medzi konštruktivistické prístupy, založené na všeobecne akceptovaných princípoch, kde si žiaci konštruujú svoju vlastnú verziu reality a nepreberajú verziu prezentovanú učitel’om (Tomengová, 2012). Základné znaky a princípy induktívneho prístupu nachádzame už v období pred našim letopočtom v učení mnohých filozofov, psychológov či pedagógov, ako sú Konfucius či Sokrates (Milton, 1987; Gentry, 1990). Významné miesto v induktívnom vzdelávaní má aj Piagetova kognitívna konštruktivistická teória a Vygotského sociálna konštruktivistická teória (Chambers, 2002). Uvedení odborníci sa sústredili najmä na aktivitu učiaceho sa v procese učenia, na úkor odovzdávania faktov a definícií (Minárechová, 2014). Induktívny prístup je špecifický tým, že vo vyučovaní vychádza $\mathrm{z}$ analýzy konkrétnych prípadov a až následne dochádza k zovšeobecneniu a formulovaniu definícií. Najbežnejšie využívanými induktívnymi metódami sú podl'a Princa a Feldera (2007) metódy výskumne (bádatel'sky) orientovaného, problémového, projektového, prípadového (situačného) či objavného vyučovania. Pri analýze konkrétnych prípadov a hladaní riešení sa u žiakov pri týchto metódach vytvára potreba poznania faktov, ktoré sú im $\mathrm{v}$ procese dodávané, alebo im je poskytnutá pomoc pri ich objavovaní (Schubertová, 2018). Tieto metódy okrem toho, že podporujú aktívne učenie sa žiakov, umožňujú tiež rozvíjat' celý rad zručností s spôsobilostí (vedeckých, sociálnych a i.). Výhody induktívneho prístupu k výučbe opisujú viacerí autori (napr. Tóthová, 2014). Vzt’ah uvedených metód k indukcii je nasledovný:

- bádatel’sky orientované vyučovanie - žiaci na vyučovacej hodine pracujú podl'a princípov vedeckej práce (od identifikácie výskumnej otázky, cez 
výber vhodných metód na overovanie predpokladov až po formuláciu záverov). Vzhl'adom na rôzny priebeh bádania a poskytnutej podpory viacerí autori (Colburn, 2000; Banchi a Bell, 2008) rozlišujú štruktúrované bádanie, sprevádzané bádanie, otvorené bádanie a potvrdzujúce bádanie.

- problémová metóda - žiaci sú postavení pred adresný problém alebo problémovú úlohu, ktorú je potrebné vyriešit' a v procese jej riešenia, vlastným pozorovaním a rozmýšl’aním žiaci objavujú nové zákonitosti, vzt’ahy medzi javmi, neobvyklé spôsoby riešenia a rozvíjajú si tvorivé myslenie (Darák, Tabaková, 1998). Problémovou úlohou môže byt' otázka, zadanie či praktická úloha (Petlák, 2004; Turek, 2014).

- $\quad$ projektová metóda - žiaci sú vedení $\mathrm{k}$ riešeniu komplexných problémov (Turek, 2014) a získavajú skúsenosti praktickou činnost'ou a experimentovaním (Průcha a kol., 1995), pričom hlavnou črtou je orientácia na produkt (Gudjons, 1986). V úvode tak stojí konkrétne zadanie ciel'a projektu, pričom sa kladie dôraz na originalitu spracovania, samostatné vyhl'adávanie, vyhodnocovanie a prezentáciu informácií.

- $\quad$ situačná metóda - nástrojom pri jej využití môže byt' konkrétna prípadová štúdia. Ide o popis reálnej situácie zo života či skutočnej udalosti, ktorá má viac riešení. Žiaci sa prostredníctvom tejto udalosti môžu lepšie vžit' do problému. Prípadová štúdia uvádza žiakov hlbšie do reality. Ich úlohou je navrhnút' riešenia či opatrenia, ktoré svojou prezentáciou ostatným predostrú (Prince, Felder, 2007). Situačné metódy sa využívajú vtedy, ked' učitel' chce viac prepájat' prax $\mathrm{s}$ teóriou.

Dôležitou otázkou, nad ktorou je pri navrhovaní konkrétnych aktivít potrebné uvažovat' je: „Akým spôsobom má byt' realizované hl'adanie riešení a odpovedí na vzniknutú otázku?" Mal byt' to byt' spôsob, ktorému žiak rozumie, ktorý prípadne sám navrhne a ktorý zabezpečí získanie relevantných údajov. Ak by sme mu tieto riešenia a odpovede transmisívne ,podsunuli“, efekt vyššie spomínaných metód by sa výrazne znížil. $Z$ tohto pohl'adu najväčšie možnosti uplatnenia v geografii ponúka pozorovanie (modelu, animácie, videa, fotografie), prieskum (terénny, medzi spolužiakmi) a najmä hl'adanie informácií v rôznych informačných zdrojoch (v mape, grafe, tabul'ke, texte, na internete a i.). Žiaci využívajú postupy v mnohom pripomínajúce prácu vedca a pri hladaní odpovedí na otázky, ktoré ich zaujímajú si rozvíjajú rozličné vedecké spôsobilosti, ako sú napríklad spôsobilost' pozorovat', usudzovat', predpokladat', klasifikovat', merat', konštruovat' grafy a tabul'ky, tvorit' závery a zovšeobecnenia. Tieto spôsobilosti, ktoré viacerí autori označujú ako spôsobilosti vedeckej práce (napr. Held, 2011) dopínajú rozvíjanie praktických zručností, ako je interpretácia mapy a grafu, orientácia sa v teréne, vyhl'adávanie informácií atd'. a d’alších - osobných a sociálnych spôsobilostí a kompetencií. Stotožňujeme sa preto s názormi odborníkov (napr. Tóthová a kol., 2017), že zmysluplným spojením sa v praxi javí 
prepojenie induktívneho a participatívneho (sociálneho) prístupu $\mathrm{k}$ vyučovaniu, kde kl'účovým zdrojom učebných skúseností (a nových poznatkov) je aktívne učenie sa za sociálnej interakcie medzi žiakmi. Žiaci pracujú a nadobúdajú poznatky spoločne, vo vzájomnej interakcii (často v skupinách) a učitel’ovou rolou je byt' sprievodcom tohto procesu, nie zdrojom poznatkov, ako je tomu pri deduktívnom prístupe.

\section{Metódy výskumu}

Príspevok predstavuje príklady geografických aktivít akcentujúcich induktívny prístup v 5. ročníku základnej školy a tematickom celku Zobrazovanie Zeme. Jednotlivé aktivity sú zamerané na získavanie zručnosti interpretácie mapy rôzneho druhu $\mathrm{v}$ digitálnej aj tlačenej podobe. Pozostávajú $\mathrm{z}$ metodických, pracovných listov a príloh. Využívajú rôzne aktivizujúce didaktické metódy a rozvíjajú rozličné spôsobilosti. Pri ich spracovaní sme využili viaceré znaky konštruktivistickej výučby, ako napr. autentické úlohy, reálny kontext, konštrukcia vedomostí, spolupráca žiakov, skúmanie a objavovanie, postupná podpora učitel'om, primárne zdroje, učitel' ako facilitátor a i. (Murphy, 1997). Súbor aktivít je spolu s d’alšími zaradený pracovného zošita (Schubertová, Škodová a kol., 2018) v rámci projektu ExpEdícia - skús, skúmaj, spoznaj (n.o. Indícia). Výsledky tvorby aktivít prezentujeme na šiestich konkrétnych vyučovacích postupoch. V príspevku sme sa zamerali na prezentáciu ich špecifík, a to je dominantná vyučovacia metóda zodpovedajúca induktívnemu prístupu, kontext aktivity, opis stimulujúcej situácie, zdroj informácií $\mathrm{k}$ riešeniu úloh a zhrnutie nadobudnutých poznatkov. Jednotlivé aktivity boli overované na 14 základných školách na Slovensku. Prostredníctvom dotazníkov spätnej väzby sme sa učitel'ov zapojených v pilotnej etape projektu (28 respondentov) pýtali na otázky: „Hodnotíte aktivitu ako vekovo primeranú? Zaujala aktivita žiakov? Opíšte silné momenty pri realizácii aktivity (konkrétne reakcie detí, výstup ich rozmýšlania/diskusie, konkrétne správanie, ktoré ukazuje, že sa niečo naučili); Pozdiel'ajte s nami otvorene aj kritické momenty pri realizácii tejto aktivity; Napriek vašej snahe a zámerom aktivity, vyskytli sa na konci jej realizácie u žiakov zásadné mylné predstavy? Uved’te aké; Ak navrhujete čokol'vek zmenit', upravit', doplnit' $v$ texte či postupe pracovného alebo metodického listu, napíšte sem konkrétnu pripomienku/návrhy“. Výsledky z tohoto overovania, ako aj postrehy z priameho pozorovania vyučovania a návrhy optimalizácie aktivít sú súčast'ou záveru príspevku.

\section{Príklady geografických aktivít využívajúcich induktívny prístup}

Naším ciel'om bolo vytvorenie aktivít, s ktorými sa žiaci vedia stotožnit', ktoré im niečo objasňujú a vysvetl'ujú, ktoré podnecujú zvedavost' a vedú $\mathrm{k}$ hl'adaniu odpovedí. Na 2. stupni základnej školy (a najmä v 5. ročníku), je väčšina 
detí ešte v štádiu konkrétnych operácií (Piaget, Inhelder, 1993). Potrebujú preto manipulovat's konkrétnymi predmetmi a prakticky skúmat', aby mohli z poznania konkrétnych jednotlivých prípadov, induktívnou cestou odvodit' zovšeobecnené tvrdenia. Aktivity k tematickému celku Zobrazovanie Zeme v rámci ISCED 2 sme navrhli v zmysle konštruktivizmu tak, aby každý žiak mal možnost' konštruovat' si svoje vlastné poznanie a využívat' pritom všetky svoje doterajšie vedomosti a skúsenosti. Popri induktívnom prístupe využívajú aj participatívny prístup, pričom žiaci riešia jednotlivé úlohy v skupinách, výsledky komunikujú v triede a $\mathrm{s}$ učitel'om.

Do pracovného zošita ExpEdícia - skús, skúmaj, spoznaj 1 (Schubertová, Škodová a kol., 2018), integrujúceho geografiu a biológiu, prostredníctvom tematických celkov $\mathrm{Z}$ mesta do dediny a Do hôr, sme navrhli $\mathrm{v}$ rámci tematického celku Zobrazovanie Zeme šest' aktivít zameraných na prácu s mapou (opísané nižšie). Aktivity vedú $\mathrm{k}$ naplneniu rámcového ciel'a geografie: Žiaci interpretujú mapy rôzneho druhu v digitálnej aj tlačenej podobe. Z hl'adiska výkonového štandardu geografie (ŠPÚ, 2014) vedú aktivity k naplneniu nasledovných ciel'ov:

- žiak vie/dokáže identifikovat’ na mape základné objekty v krajine (vie „čítat"“ obsah mapy),

- žiak vie/dokáže vyhl'adat' konkrétne miesta na digitálnych mapách,

- žiak vie/dokáže porovnat' na mapách rôznych grafických mierok vzdialenosti,

- žiak vie/dokáže vytýčit' trasu geografickej exkurzie (vychádzky) a slovne opísat' jej priebeh,

- žiak vie/dokáže pomocou prístroja GPS (mobilu) nájst' zaujímavé miesto,

- žiak vie/dokáže odhadnút' vzdialenosti k zaujímavým bodom na mape a náročnost' prístupu k ním,

- Žiak vie/dokáže zosumarizovat' zmeny v ovzduší so stúpajúcou výškou.

Aktivity rozvíjajú celý rad kognitívnych a funkčných, osobných, sociálnych a komunikačných kompetencií. Žiaci získavajú praktické zručnosti pri tvorbe, interpretácii obsahu mapy a jej praktickom použivaní v rôznych situáciách. Tieto zručnosti získavajú prostredníctvom zadaní reálnych komplexných úloh zo života, ktoré riešia $v$ rámci skupín, čím žiaci získavajú zručnosti v komunikácii a argumentácii. Navrhnuté aktivity majú vel'ký potenciál rozvíjat' aj spôsobilosti vedeckej práce ako sú napríklad spôsobilost' pozorovat', predpokladat', merat', konštruovat' tabul'ky, usudzovat', spôsobilost' tvorit' závery a zovšeobecnenia. Úspešnost' vyučovacieho procesu závisí okrem iného od motivácie žiakov, ale tiež od toho, čo z danej témy už vedia a ako to vedia využit' pri učení sa nových vecí. Preto v úvode každej aktivity využívame vtipný komix, ktorý otvára diskusiu, 
ktorá vyústuje do formulácie výskumnej otázky, v niektorých prípadoch aj predpokladov. Až v záveroch aktivít dochádza ku generalizácii a formulácii definícií v podobe záverov či zhrnutí. Predstavujeme klúčové prvky jednotlivých aktivít:

\section{Mapa Bubántanu}

Dominantná metóda: projektová metóda

Kontext: Princíp spočíva $\mathrm{v}$ pochopení textu a schopnosti prečítané informácie previest' do grafickej podoby v podobe mapy. Ciel'om je nakreslit' mapu fiktívneho hlavného mesta fiktívnej krajiny opísaného textom v pracovnom zošite. Žiaci sa pri riešení tejto úlohy stretnú s bežnými kartografickými problémami od generalizácie cez výber vhodných prvkov na zakreslenie a ich zaradenie do skupín až po tvorbu funkčného značkového kl'úča (súboru mapových značiek a symbolov).

Stimulujúca situácia: Diskusia o neznámych a tajomných mestách (napr. Trója). Zdroj informácií $\mathbf{k}$ riešeniu úloh: Text o fiktívnom meste Bubántan v pracovnom zošite.

Zhrnutie nadobudnutých poznatkov: Pri tvorbe mapy je nevyhnutné obraz Zeme zjednodušit'. Na vyjadrenie objektov v mape využívame mapové značky, ktoré môžu mat' plošný, líniový alebo bodový charakter.

\section{Ako sa nestratit' $v$ meste}

Dominantná metóda: problémová metóda

Kontext: Žiaci v úvode aktivity kreslia svoju predstavu trasy zo školy do centra mesta. Zist'ujú, že ich predstavy sú rôzne a nie sú presné. Zoznamujú sa s mapou ich mesta, zorientujú ju podl'a svetových strán s pomocou buzoly (môžu si vyrobit' jednoduchý kompas), učia sa mapu ,čítat““. Trasu do centra mesta si tentokrát prekreslia už presnejšie - z mapy. Zoznamujú sa s Google Earth a Street view a prejdú si trasu aj virtuálne.

Stimulujúca situácia: Diskusia $\mathrm{k}$ úvodnému komixu: „Boli ste už v podobnej situácii ako Teo?" (má vybitý mobil, nevie, ako sa dostane na zástavku autobusu), „Čo vám pomohlo?"

Zdroj informácií k riešeniu úloh: vlastná skúsenost', mapa

Zhrnutie nadobudnutých poznatkov: Obsah mapy vyjadruje všetko to, čo je priamo viditel'né na zemskom povrchu. Mapa musí spíňat' niektoré dôležité parametre. Musí napríklad obsahovat' legendu a byt' správne zorientovaná voči svetovým stranám.

\section{Hlavolamy na mapách}

Dominantná metóda: prípadová štúdia

Kontext: Žiaci v úvode aktivity diskutujú o možných podobách máp v súvislosti s ciel'om ich využitia. Nasleduje interpretácia a porovnanie obsahu štyroch máp v rôznej mierke. Prostredníctvom tejto úlohy žiaci pochopia súvislost' medzi mierkou 
mapy a generalizáciou jej obsahu. Získajú zručnosti pri používaní mierky mapy.

Stimulujúca situácia: Diskusia k úvodnému komixu (Teo má GPS, atlas, mapu a aj tak v nich nevie nájst', čo potrebuje): „Ako môžu vyzerat' mapy a prečo nemôže byt'v mape zobrazené všetko?"

Zdroj informácií $\mathbf{k}$ riešeniu úloh: mapy rôznych druhov a mierok

Zhrnutie nadobudnutých poznatkov: Pri zmenšení a skreslení skutočnosti, ktorá je súčast’ou tvorby mapy nie je možné zachovat' na mape všetky prvky, ktoré sa nachádzajú na zemskom povrchu. Obraz je nutné zjednodušit' - napr. vynechaním niektorých miest a objektov. Zmenšenie obrazu Zeme oproti skutočnosti vyjadruje mierka mapy.

\section{Mapovacia výprava}

Dominantná metóda: terénne metódy

Kontext: Žiaci v skupinách naplánujú a zrealizujú vychádzku do blízkeho okolia školy. Počas nej sa zdokonal'ujú v orientácii sa v prírode s pomocou mapy, buzoly, GPS a i. Pri presahu do biológie žiaci na trase vychádzky vyhl'adávajú, pozorujú a zaznamenávajú živé a neživé časti prírody. Prezentujú získané výsledky. Ak je aktivita realizovaná len $\mathrm{v}$ rámci geografie, pozorovanie živých a neživých častí prírody sa vynechá.

Stimulujúca situácia: Úvodný komix (medved' pozoruje lupou mravca, Teo pozerá do d'alekohl'adu).

Zdroj informácií $\mathbf{k}$ riešeniu úloh: pozorovanie krajiny, mapa

Zhrnutie nadobudnutých poznatkov: Pohyb v prírode vyžaduje zručnost’ v orientovaní sa $\mathrm{s}$ pomocou mapy a kompasu. Prírodu tvoria prírodniny, ktoré rozdel'ujeme na živé a neživé. Môžeme ich pozorovat' vol’ným okom, lupou alebo d’alekohl'adom. Lupou pozorujeme prírodniny, ktoré sú malé a sú blízko, d'alekohl'adom pozorujeme vzdialené prírodniny.

\section{Kl'ukaté vrstevnice}

Dominantná metóda: bádatel'sky orientované vyučovanie

Kontext: V úvode aktivity žiaci diskutujú o turistickej výstroji potrebnej do hôr. Zoznamujú sa s turistickou mapou a jej obsahom. Vytvoria si v skupine vlastný 3D model pohoria, ktorý prevedú do podoby vrstevníc. Pochopia tak súvislost' medzi členitostou reliéfu a vrstevnicami v mape. Žiaci následne pracujú s vrstevnicami, na ich základe určujú nadmorskú výšku a výškový rozdiel miest na mape.

Stimulujúca situácia: Diskusia k úvodnému komixu (medved’ a Teo rozmýšlajú nad tým, čo všetko si majú zbalit’ do malého turistického batoha): „Čo všetko tvori nevyhnutnú turistickú výbavu do hôr?"“

Zdroj informácií $\mathbf{k}$ riešeniu úloh: manipulácia s modelom

Zhrnutie nadobudnutých poznatkov: Turistická mapa patrí k nevyhnutnej turistickej výbave. Vrstevnice v turistickej mape pomáhajú spravit'si predstavu o náročnosti túry. Vrstevnice sú čiary, ktoré spájajú body s rovnakou nadmorskou 
výškou. Č́m sú na mape hustejšie pri sebe, tým je svah kopca, ktorý znázorňujú strmší a naopak.

\section{Výstup na vrchol pohoria}

Dominantná metóda: prípadová štúdia

Kontext: V úvode aktivity žiaci formulujú predpoklad o zmene teploty a vlhkosti so stúpajúcou nadmorskou výškou. Predpoklad overujú na základe sprostredkovaných informácií, ktoré mohli Teo s medved’om získat' počas výstupu na vrchol pohoria. Žiaci pracujú $\mathrm{s}$ informáciami $\mathrm{v}$ mape, tabul'ke a získané informácie prepájajú a schematizujú.

Stimulujúca situácia: Diskusia k úvodnému komixu (medved' a Teo stúpajú do kopca): „Ako a prečo sa mení ovzdušie (jeho teplota) pri stúpaní na vrchol pohoria?"

Zdroj informácií $\mathbf{k}$ riešeniu úloh: mapa, dáta $\mathrm{v}$ tabul'ke pracovného zošita Zhrnutie nadobudnutých poznatkov: $S$ rastom nadmorskej výšky teplota vzduchu rovnomerne klesá. Nadmorskú výšku vyčítame $\mathrm{z}$ mapy s pomocou vrstevníc a kót.

\section{Záver}

Predložené ukážky kl’účových prvkov aktivít majú snahu ukázat', ako môže byt' súčasný obsah tematického celku Zobrazovanie Zeme v 5. ročníku sprístupňovaný induktívnym spôsobom. Z dotazníka spätnej väzby učitel'ov zapojených do pilotného overovania aktivít vyplýva, že prínos videli najmä vo zvýšení záujmu žiakov o predmet, väčšej aktivizácii a spolupráci žiakov, zaujímavých formách učenia sa, zmenách v myslení učitel'a, efektívnejšiej príprave učitel'a, lepšom pocite zo svojej práce a i. Ako riziká uvádzali najmä nedostatok času potrebného na realizáciu niektorých aktivít, problém hodnotenia skupinovej práce, náročnejšiu prípravu pomôcok a iné problémy, ktoré s učitel'mi komunikujeme na školeniach. Z priameho pozorovania vyučovacieho procesu vyplýva, že žiaci aj učitelia si musia na induktívny prístup k vyučovaniu zvyknút', aby ho dokázali plne využit'. Učitelia mali najväčší problém s interakciou so žiackym svetom, so vzbudením zvedavosti a predstavením problému alebo situácie tak, aby bola pre žiaka relevantná. Často mali problém interagovat' so žiackou skúsenost'ou a zisteniami, ktoré nevedeli vždy dopredu predpokladat'. Optimalizácia aktivít spočíva najmä v precíznejšej štrukturácii pracovných listov pre žiaka (situácia/problém, záznam žiackej skúseností, predpokladu, návrhu jeho overenia, záznam údajov, vyhodnotenie údajov formulujúc záver, návrat $\mathrm{k}$ úvodnej situácii a predpokladom) (Kotuláková, 2018). Ďalšie overovanie aktivít v budúcnosti prinesie aj teoretické poznatky o zmene individuálnej koncepcie učitel'a vplyvom využívania navrhnutých aktivít a školení k nim. 


\section{Pod'akovanie}

Príspevok bol spracovaný v rámci projektu projektu ExpEdicia, ktorý realizuje nezisková organizácia Indícia a sfinančnou podporou Kultúrnej a grantovej agentúry Ministerstva školstva SR - grant KEGA O02UMB-4/2017 „Interaktívna elektronická učebnica regionálnej geografie Horného Pohronia “.

\section{Literatúra}

BANCHI, H. - BELL, R. 2008. The Many Levels of Inquiry. In Science and Children. ISSN 0036-8148, 2008, vol. 46, no. 2, pp. 26-29.

COLBURN, A. 2000. An inquiry primer. In Science Scope. ISSN 0887-2376, 2000, vol. 23, no. 6, pp. 42-44.

CHAMBERS, C. 2002. Multi-Curricular Inquiry-Based Learning [online]. New York: City College of the City University of New York. [online]. 2002. [cit. 2018-9-12]. Dostupné na internete: <http://condor.admin.ccny.cuny.edu/ $\sim$ group5/carlchambers.researchpaper.doc $>$.

DARÁK, M. - TABAKOVÁ, K. 1998. Základy pedagogiky. Terminologické minimum. Prešov: ManaCon, 1998. 123 s. ISBN 80-85668-72-6.

GENTRY, J. W. C. 1990. What is experiential learning? In Guide to business gaining and experiential learning. East Brunswick: CN: Nichols/GP Publishing, 1990. pp. 9-20.

GUDJONS, H. 1986. Handlungsorientiert lehren und lernen: Projektunterricht und schüleraktivität. Bad Heilbronn: Klinkhardt, 1986. 113 p. ISBN 3781504417.

HELD, L. a kol. 2011. Výskumne ladená koncepcia prírodovedného vzdelávania (IBSE v slovenskom kontexte). Trnava: Typi Universitatis Tyrnaviensis, 2011. 138 s. ISBN 978-80-8082-486-0.

KOTULÁKOVÁ, K. 2018. Spôsobilosti učitel'ov viest' konštruktivisticky orientovanú výučbu prírodovedných predmetov. Interný materiál n.o. Indície, $18 \mathrm{~s}$.

MILTON, J. R. 1987. Induction before Hume. In British Journal for the Philosophy of Science. vol. 38, no. 1, pp. 49-74.

MINÁRECHOVÁ, M. 2014. História induktívneho prístupu v prírodovednom vzdelávaní v USA a jeho súčasná reflexia na Slovensku. In Scientia in educatione. ISSN 1804-7106, 2014, vol. 5, no. 1, pp. 2-19.

MURPHY, E. 1997. Constructivism from philosophy to practice. Maryland: ERIC Processing and Reference Facility, 1997. 18 p.

PASCH, M. a kol. 1998. Od vzdělávacího programu $k$ vyučovaci hodině: Jak pracovat s kurikulem. Praha: Portál, 1998. 424 s. ISBN 80-7178-127-4.

PETLÁK, E. V̌̌eobecná didaktika. Bratislava: IRIS, 2004. 311 s. ISBN 80-8901864-5. 
PIAGET, J. - INHELDER, B. 1993. Psychológia diet'at'a. Bratislava: SOFA, 1993. 144 s. ISBN 80-85752-33-6.

PRINCE, M. - FELDER, R. 2007. The Many Faces of Inductive Teaching and Learning. In Journal of College Science Teaching. ISSN 0047-231X, 2007, vol. 36 , no. 5 , pp. $14-20$.

PRŮCHA, J. - WALTEROVÁ, E. - MAREŠ. J. 1995. Pedagogický slovník. Praha: Portál, 1995. 292 s. ISBN 80-7178-029-4.

SCHUBERTOVÁ, R. 2018. Návrh na induktívne sprístupnenie tém o adaptácii organizmov. In Inovativne trendy $v$ odborových didaktikách $v$ kontexte požiadaviek praxe. Nitra: PF UKF v Nitre. 2018. ISBN 978-80-558-1277-9, s. 86-92.

SCHUBERTOVÁ, R. - ŠKODOVÁ, M. - CHRENKOVÁ, M. - BALÁŽOVIČ, L'. 2018. ExpEdícia - skús, skúmaj, spoznaj 1, Biológia a geografia pre 5. roč. ZŠ. Bratislava: Indícia, s.r.o., 2018. 73 s. ISBN 978-80-89859-18-4.

ŠPÚ, 2014. Inovovaný Štátny vzdelávaci program: Geografia - nižšie stredné vzdelávanie [online]. Bratislava: ŠPÚ [cit. 2018-09-21]. Dostupné na internete: $<$ http://www.statpedu.sk/files/articles/dokumenty/inovovany-statny-vzdelavaciprogram/geografia_nsv_2014.pdf >.

ŠPÚ, 2015. Metodika pre vzdelávaciu oblast' Človek a spoločnost' - nižšie stredné vzdelávanie [online]. [cit. 2018-09-22]. Dostupné na internete: <http://www.statpedu.sk/images/sk/svp/zavadzanie-isvp-ms-zs-gym/zakladnasola/metodiky/metodika-vzdelavaciu-oblast-clovek-spolocnost-3-verzia.pdf > .

TOMENGOVÁ, A. 2012. Aktívne učenie sa žiakov - stratégie a metódy. Bratislava: MPC, 2012. 63 s. ISBN 978-80-8052-421-0.

TÓTHOVÁ, R. 2014. Konštruktivistický prístup vo výučbe ako možnost' rozvoja myslenia žiakov. Bratislava: MPC, 2014. 90 s. ISBN 978-80-565-0004-0.

TÓTHOVÁ, R. - KOSTRUB D. - FERKOVÁ, Š. 2017. Žiak, učitel' a výučba (Všeobecná didaktika pre študentov učitel'stva). Prešov: Rokus publishing, 2017. 370 s. ISBN 978-80-89510-61-0.

TUREK, I. 2014. Didaktika. Bratislava: Wolters Kluwer, 2014. 620 s. ISBN 97880-8168-004-5.

\section{EXAMPLES OF THE INDUCTIVE APPROACH APPLICATION IN TEACHING ABOUT IMAGING EARTH IN ELEMENTARY SCHOOL}

\section{Summary}

Although there is still a predominant deductive method of teaching in Slovak schools, there are many projects that develop an inductive way of teaching and learning. One of them is the project ExpEdition - Experience, Explore, Know (non-profit organization Indícia). The article presents the theoretical framework of the possibility of inductive access in geographic education. It represents a concrete 
design of activities in which students acquire knowledge and skills in mapping. We used several features of constructivist approach in teaching, such as authentic tasks, real context, knowledge design, student collaboration, exploration and discovery, step-by-step support for teachers, primary resources, teacher as a facilitator, and others. We present the results of the activities on six specific teaching models. In this paper, we have focused on the presentation of their specifics, namely the dominant teaching method corresponding to the inductive approach, the context of the activity, the description of the stimulating situation, the source of the information to solve the problems and the summary of the acquired knowledge. We have verified the individual activities in 14 primary schools in Slovakia. Further verification of activities in the future will bring the theoretical knowledge about changing the individual concept of a teacher through the use of the proposed activities and training.

\section{RNDr. Martina Škodová, PhD.}

Katedra geografie a geológie

Fakulta prírodných vied

Univerzita Mateja Bela v Banskej Bystrici

Tajovského 40, 97401 Banská Bystrica

E-mail: martina.skodova@umb.sk 